\title{
Evaluation of the quality of sunflower oil subjected to frying processes under controlled conditions
}

\section{Avaliação da qualidade de óleo de girassol submetido a processos de fritura em condições controladas}

\author{
Thiago Taham ${ }^{1 *}$; Shirlei Monai dos Santos ${ }^{2}$
}

\begin{abstract}
${ }^{1}$ Autor para correspondência. Doutor em Engenharia Química pela Universidade Federal de Uberlândia (2016), docente do Instituto Federal de Educação, Ciência e Tecnologia do Triângulo Mineiro, Campus Uberlândia. Fazenda Sobradinho s/n, Zona Rural - Uberlândia /MG, CEP 38400-970. Fone (34) 32338878, e-mail: thiago.taham@iftm.edu.br

${ }^{2}$ Graduada no curso Superior de Tecnologia em Alimentos (2015), no Instituto Federal de Educação, Ciência e Tecnologia do Triângulo Mineiro, Campus Uberlândia. Fazenda Sobradinho s/n, Zona Rural - Uberlândia /MG, CEP 38400-970. Fone (34) 32338878, e-mail: shirleimonaicp@hotmail.com
\end{abstract}

\section{Recebido em: 07-09-2016; Aceito em: 28-12-2016}

\begin{abstract}
The food frying process causes physicochemical modifications in the oils, affecting their sensorial characteristics and eventually producing toxic effects. The objective of this work was to study the degradation of sunflower oil used in potato immersion frying, considering the free fatty acid content, peroxide index and refractive index, highlighting the critical and optimal points of the process. Experimental planning and response surfaces were used, considering the variables temperature, total process time and potato:oil ratio. The three variables showed a significant linear effect on the percentage of free fatty acids $\left(R^{2}=98.3 \%\right)$. The value of the peroxide index was strongly influenced by temperature and, to a lesser extent, by other variables $\left(R^{2}=98 \%\right)$. The refractive index was influenced linearly and quadratically by time and temperature and only linearly by the potato:oil ratio $\left(R^{2}=97.2 \%\right)$. These results indicate that frying processes conducted at warmer temperatures may increase the useful life of the oil, whose characteristics directly influence the quality of the final product.
\end{abstract}

Additional keywords: experimental planning; free fatty acids; quality control; thermal processes; vegetable oils.

\begin{abstract}
Resumo
O processo de fritura dos alimentos causa modificações físico-químicas nos óleos, afetando suas características sensoriais e podendo produzir efeitos tóxicos. Este trabalho objetivou estudar a degradação do óleo de girassol utilizado na fritura por imersão de batatas, considerando a concentração dos ácidos graxos livres, índice de peróxido e índice de refração, destacando os pontos críticos e ótimos do processo. Utilizou-se a ferramenta de planejamento experimental e superfícies de resposta, sendo as variáveis consideradas a temperatura, o tempo total do processo e proporção entre batatas e o óleo. As três variáveis mostraram efeito significativo e linear na porcentagem de ácidos graxos livres $\left(R^{2}=98,3 \%\right)$. O valor do índice de peróxidos foi fortemente influenciado pela temperatura e, em menor proporção, pelas outras variáveis $\left(R^{2}=98 \%\right)$. O índice de refração sofreu influência linear e quadrática do tempo e da temperatura e apenas linear da proporção batatas/óleo $\left(R^{2}=97,2 \%\right)$. Estes resultados indicam que processos de fritura conduzidos em temperaturas mais amenas podem aumentar a vida útil do óleo, cujas características influenciam diretamente na qualidade do produto final.
\end{abstract}

Palavras-chave adicionais: ácidos graxos livres; controle de qualidade; óleos vegetais; planejamento experimental; processos térmicos.

\section{Introduction}

The Food and Agricultural Policy Research Institute (FAPRI) report, which analyzes various issues related to world agriculture since 2005 (including the market for seeds, bran, protein cakes and vegetable oils), points to a continuous increase in the consumption of vegetable oils, dairy products and protein cakes and bran in most countries of the world (Vernetti, 2015). In this scenario, sunflower oil stands out, being fourth placed in terms of world production and consumption, representing $8 \%$ of the total oilseed production. The first place belongs to the palm, with $32 \%$, followed by the soybean, with $29 \%$ and the rapeseed, with $16 \%$. The predominance of the first two refers to their use also for biodiesel production (USDA, 2011). In Brazil, sunflower productivity is above the world average (1300 kg/ha against $2000 \mathrm{~kg} / \mathrm{ha}$ in Brazil), although its production is not among the 10 largest in the world (Embrapa, 2016).

The consumption of fried and pre-fried foods increased in recent years, which led to an increase in the intake of oils and fats after having been subjected to high temperatures in the frying process (Ans et al., 1999; Gimeno et al., 2011). It has been noted that this fact has been influenced by social, economic and technical reasons, since people have less time to pre- 
pare their food and, thus, the frying process provides an alternative for rapid preparation, while providing pleasant sensory characteristics to the fried foods.

The frying process is generally carried out in open containers, at elevated temperatures $\left(180-200^{\circ} \mathrm{C}\right)$, in direct contact with the air. These conditions cause physicochemical modifications in the oils (thermooxidation, rancidification, hydrolysis), some of which are visible, such as darkening, viscosity increase, foaming and smoke. These transformations affect the sensory characteristics of the oil in use and influence the acceptability of the fried product, as well as produce toxic effects such as gastrointestinal irritation, inhibition of enzymes, destruction of vitamins and carcinogenesis when the case is a continuous and prolonged ingestion of rancid products (Freire et al., 2013). In addition, there is evidence that laboratory animals, fed on deep frying processed oils, may exhibit metabolic alterations that result in weight loss, growth suppression and increased liver cholesterol (Block \& Barrera-Arellano, 2009).

During the heating of the oil in the frying process, a complex series of reactions produces numerous degradation compounds. With the course of the reactions, the functional, sensorial and nutritional qualities change. When the food is submerged in the hot oil in the presence of air, the oil is exposed to three agents that cause changes in its structure: the water from the food itself, leading to hydrolytic changes; the oxygen that comes in contact with the oil and from its surface leads to oxidative changes and, finally, the temperature at which the process occurs, resulting in thermal changes, such as isomerization (formation of trans fatty acids) and scission reactions (aldehydes and ketones), forming several degradation products, such as epoxides and hydroperoxides (Jorge et al., 2006).

The thermal stability of the oils depends on their chemical structure: oils with saturated fatty acids are more stable than the unsaturated ones, although the latter are the most widely spread and used types. Sunflower oil, for example, has a composition of $86.10 \%$ unsaturated fatty acids and $13.9 \%$ saturated fatty acids. In soybean oil, this ratio is $84.15 \%$ unsaturated and $15.85 \%$ saturated. The predominant unsaturated fatty acids are the oleic, linoleic and linolenic, with linoleic predominance in both cases (Food Ingredients Brasil, 2014). It is worth mentioning that in sunflower oil the proportion of linolenic acid $(0.15 \%)$ is substantially lower than in soybean oil $(4.72 \%)$, which makes it a more indicated oil for frying, since the presence of the three double bonds of linolenic acid makes it much more susceptible to oxidation (Osawa, 2010)

Since oils with high levels of unsaturated fatty acids are widely used in cooking and in the industry, researchers and specialized technicians have been asked to study new analytical methods capable of evaluating processing and storage conditions. Based on the above, several countries have established technical regulations to control the quality of oils and fats used for frying, setting maximum limits for polar compounds, ranging from 24 to $27 \%$, and, in some of them, also for \% FFA, which is $1.0 \%$, expressed as oleic acid (Lima \& Gonçalves, 1994; Dobarganes, 2000). In Brazil, the legislation establishes only the maximum temperature of $180^{\circ} \mathrm{C}$ during frying (Brasil, 2004a), while the percentage of free fatty acids (maximum value of $0.9 \%$ ) and polar compounds (maximum of $25 \%$ ) are given according to a technical report (Brasil, 2004b).

The ways to determine when an oil has reached the point of discard are not simple. Many different foods are fried in different types of oil, in various types of containers, in long periods and very different operating conditions. The combination of all these variables is what determines the rate at which degradation reactions occur and therefore a specific method may be good for evaluating in one system and not be applicable to others (Choe \& Min, 2007). Thus, it is necessary to have control methods to evaluate the change produced, as well as to seek objective criteria to define when the oils should be discarded. In this context, the objective of the present work was to evaluate the physicochemical alterations of the sunflower oil subjected to the stress originating from the frying process of potatoes and to evaluate, among the studied variables (temperature, frying time and potato:oil ratio), which had greater influence on the final quality of the oil, measured by the \% FFA, peroxide index and refractive index responses.

\section{Material and methods}

The material used (sunflower vegetable oil and potatoes) was purchased in a local market, in the city of Uberlândia - MG. All purchased vegetable oil was homogenized in a polypropylene canister to avoid batch differences. At the time of the experiment the potatoes were peeled and then sliced with an electric slicer (brand REPHALE), with thicknesses between 1-1.5 mm, to increase the contact surface.

\section{Experimental Planning}

To evaluate the effect of the variables on the responses, a $2^{3}$ experimental design was performed, totaling 17 experiments ( 3 central points). The independent variables were temperature - $X_{1}$, which ranged from 100 to $200^{\circ} \mathrm{C}$; frying time - $X_{2}$, which ranged from 1.25 to $12.75 \mathrm{~h}$; and the potato:oil ratio - $\mathrm{X}_{3}$, which ranged from 0 to 0.5 . The responses of interest were \% free fatty acids $\left(Y_{1}\right)$, peroxide index $\left(Y_{2}\right)$ and refractive index $\left(\mathrm{Y}_{3}\right)$. Table 1 summarizes the experimental conditions used.

The reliability of the responses was verified by the proximity of the results of the experiments in the central point and by the value of the regression coefficient $\left(R^{2}\right)$. The experiments were conducted on different days and in an order different than that described above, so as not to interfere with the analysis of the results and, mainly, to merge the central points in the center of the experimental design. The variables and responses obtained have been inserted in the STATISTICA $\AA$ software for estimation of effects, analysis of variance, and construction of response surfaces, in which only the significant effects were considered. 
Table 1 - Experimental design performed.

\begin{tabular}{ccccccc}
\hline Experiment & $\mathrm{X}_{1}$ & $\mathrm{X}_{2}$ & $\mathrm{X}_{3}$ & $\mathrm{~T}\left({ }^{\circ} \mathrm{C}\right)$ & $\mathrm{t}(\mathrm{h})$ & Proportion \\
\hline 1 & -1 & -1 & -1 & 120 & 4 & 0.1 \\
2 & +1 & -1 & -1 & 180 & 4 & 0.1 \\
3 & -1 & +1 & -1 & 120 & 10 & 0.1 \\
4 & +1 & +1 & -1 & 180 & 10 & 0.1 \\
5 & -1 & -1 & +1 & 120 & 4 & 0.4 \\
6 & +1 & -1 & +1 & 180 & 4 & 0.4 \\
7 & -1 & +1 & +1 & 120 & 10 & 0.4 \\
8 & +1 & +1 & +1 & 180 & 10 & 0.4 \\
9 & $-\alpha$ & 0 & 0 & 100 & 7 & 0.25 \\
10 & $+\alpha$ & 0 & 0 & 200 & 7 & 0.25 \\
11 & 0 & $-\alpha$ & 0 & 150 & 1.25 & 0.25 \\
12 & 0 & $+\alpha$ & 0 & 150 & 12.75 & 0.25 \\
13 & 0 & 0 & $-\alpha$ & 150 & 7 & 0 \\
14 & 0 & 0 & $+\alpha$ & 150 & 7 & 0.5 \\
15 & 0 & 0 & 0 & 150 & 7 & 0.25 \\
16 & 0 & 0 & 0 & 150 & 7 & 0.25 \\
17 & 0 & 0 & 0 & 150 & 7 & 0.25 \\
\hline
\end{tabular}

The immersion frying was conducted in a 5-liter commercial electric fryer with temperature control, respecting the experimental planning table (Table 1). At each experiment, the first step was to collect a sample of the oil for analysis and initial quality verification in terms of free fatty acid content, peroxide index and refractive index. During the conduction of the experiments, the temperature was also checked with a manual thermometer to avoid calibration errors of the digital display of the electric fryer. At the end of the experiment, oil samples were collected in capped test tubes, duly identified and stored in the dark, under refrigeration, until analysis.

\section{Analyses}

The analyses were carried out on both the potatoes and the pre- and post-frying oil. In the potatoes, a moisture analysis was carried out according to the greenhouse method at $105{ }^{\circ} \mathrm{C}$ for $24 \mathrm{~h}-\mathrm{Ca} 2 \mathrm{c}-5$ method (AOCS, 2009), only to ensure that the raw materials used had an approximate moisture content, thus not interfering with the responses.

Analyses of free fatty acid content (\% FFA), refractive index and peroxide index were performed in the oil. The free fatty acid content was determined by titration with sodium hydroxide $(\mathrm{NaOH})$, by the cold method 2201 of IUPAC (1979). Measurement of the oxidation compounds was done using the official method Cd8-53 (American Oil Chemists' Society AOCS, 2009). This method determines all substances in terms of milliequivalents (meq) of peroxide per 1000 $\mathrm{g}$ of sample which oxidize the potassium iodide under the test conditions. These substances are generally considered as peroxides or other similar products resulting from the oxidation of fat. Measurement of the refractive index of the samples was done using the official method Cc7-25 (AOCS, 2009). This value is related to the degree of saturation of the bonds, but is affected by other factors such as free fatty acid content, oxidation and heat treatment, being a good indicator of degradation. The reading was done in a refractometer using the solvent petroleum ether as a diluent.

\section{Results and discussion}

The average moisture of the potatoes was $79.97 \pm 0.52 \%$, which agrees with the experimental results found by Quadros et al. (2009).

The experimental responses are presented in Table 2. The \% FFA of the oil before any processing, expressed as percentage of oleic acid, was equal to $0.12 \%$. After the frying process, the results found for the \%FFA response were outside the limits established both by international technical regulations (maximum of $1.0 \%$ - Lima \& Gonçalves, 1995; Dobarganes, 2000) and by a Brazilian technical report (maximum of $0.9 \%$ - Brasil, 2004b) in 11 of the 17 trials performed. This fact is due to both the experimental conditions applied and the composition of the oil itself, which presents a higher unsaturation of fatty acids and is therefore more prone to hydrolysis reaction. Among these, the highest values found for the \% FFA response (> $2 \%$ ) occurred in experiments 8 and 10 . In experiment 8 , a combination of high values (coded level +1 ) was observed in the 3 independent variables, which is strongly non-ideal for a frying process. In experiment 10, the highest temperature of all experimental design was applied, which shows that this variable presents a strong interference in the free fatty acid content. Similar results were found in the experimental work of Jorge et al. (2005), whose results showed that, after 7.5 hours of potato frying, sunflower oil already reached $1.1 \%$ FFA. 
Table 2 - Free fatty acid content (\% FFA), peroxide index and refractive index as function of experiments.

\begin{tabular}{lccc}
\hline Experiment & FFA $(\%)$ & Peroxide index $(\mathrm{meq} / \mathrm{kg})$ & Refractive index \\
\hline 1 & 0.34 & 8.01 & 1.4634 \\
2 & 1.10 & 12.01 & 1.4680 \\
3 & 0.75 & 8.00 & 1.4666 \\
4 & 1.60 & 15.01 & 1.4790 \\
5 & 0.75 & 8.00 & 1.4690 \\
6 & 1.40 & 14.01 & 1.4730 \\
7 & 1.16 & 12.01 & 1.4685 \\
8 & 2.01 & 20.00 & 1.4850 \\
9 & 0.46 & 7.00 & 1.4625 \\
10 & 2.10 & 20.01 & 1.4820 \\
11 & 0.71 & 6.00 & 1.4685 \\
12 & 1.63 & 15.01 & 1.4750 \\
13 & 0.74 & 10.00 & 1.4676 \\
14 & 1.50 & 14.00 & 1.4720 \\
15 & 1.23 & 10.54 & 1.4670 \\
16 & 1.29 & 10.15 & 1.4690 \\
17 & 1.12 & 10.01 & 1.4685 \\
\hline
\end{tabular}

The lowest values of \% FFA, in turn, were obtained in experiments 1 and 9 . In experiment 1 , a combination of low values (coded levels -1 ) could be observed for the 3 variables studied. In experiment 9 , the lowest temperature of all experimental design was applied, which confirms the previous analysis that indicates a strong influence of this variable on the responses.

At the beginning of the experiments, the peroxide index was $0.99 \mathrm{meq} / \mathrm{kg}$ oil. After performing the experimental design, several values of this index were outside the limits permitted by the norms that regulate the quality of vegetable oils for consumption in Brazil (RDC 270/05 - Anvisa), which establish that for cotton, sunflower and palm oils, the maximum value for the peroxide index should be $10 \mathrm{meg} / \mathrm{kg}$. The highest values (>20 meq $/ \mathrm{kg}$ ) also occurred in experiments 8 and 10 , showing the strong influence of temperature and its relationship with other variables. Jorge et al. (2005) also found, in potato frying with sunflower oil at $180^{\circ} \mathrm{C}$, values higher than $20 \mathrm{meq} / \mathrm{kg}$, in times higher than $8 \mathrm{~h}$ of process. According to Monferrer and Vollalta (1993), this response can act as a quality parameter that indicates as the point of oil discard that when it reaches values higher than $15 \mathrm{meq} / \mathrm{kg}$. The peroxide index values were lower in experiments 9 and 11 , where the lowest temperature (9) and the shortest process time (11) were respectively applied. However, it is worth noting that the peroxide index does not present a linear behavior, since at the stage of advanced oil degradation its value declines (Freire et al., 2013). Thus, the peroxide index cannot be used as the only indicator of oil quality.

The refractive index values showed little or no variation from the initial value, which was 1.4605 . Del Ré \& Jorge (2007) studied the behavior of the refractive index of sunflower oil after the frying of hamburg- ers; the results were similar, with little variation of this quality parameter.

The experimental variables and responses were included in the STATISTICA® software to evaluate the effects of the variables on the responses of interest, as shown in Table 3.

The temperature was the variable with the greatest influence on the \% FFA, followed by the time and the potato:oil ratio. The linear influence of all variables was higher, indicating a linear behavior of the response surfaces, and the coefficient of determination $\left(R^{2}\right)$ was $98.3 \%$.

The temperature and the process time were the variables with the greatest influence on the peroxide index, followed by the ratio. In this case, more terms were statistically significant, giving greater complexity to the adjusted equation, which presented a high coefficient of determination (98.0\%).

The refractive index, although with little variation, was also more affected by the temperature and process time, and the interaction between these variables was likewise a statistically significant term. The coefficient of determination, in this case, was equal to $97.2 \%$. Figure $1(\mathrm{a}, \mathrm{b}, \mathrm{c})$ shows the surfaces constructed for each response, combined with a pair of independent variables. For the construction of the curves, statistically non-significant terms were excluded from the model.

Figure 1a shows that high temperatures combined with a long exposure time are detrimental to the quality of the sunflower oil in terms of its free fatty acid content. Milder temperatures, in turn, can increase its useful life, even if it is exposed to a longer process time. Similar results were obtained in the experimental study with soybean oil conducted by Silvani \& Taham (2013). 
Table 3 - Effect of independent variables upon responses of free fatty acid content (FFA), peroxide index and refractive index.

\begin{tabular}{lcccccc}
\hline & \multicolumn{2}{c}{ FFA } & \multicolumn{2}{c}{ Peroxide index } & \multicolumn{2}{c}{ Refractive index } \\
\hline Coded variable & Effect & Value-p & Effect & Value-p & Effect & Value-p \\
\hline média & 1.216 & 0.000 & 10.317 & 0.000 & 1.468 & 0.000 \\
$\mathrm{X}_{1}(\mathrm{~T})$ & 0.862 & 0.000 & 6.887 & 0.000 & 0.010 & 0.000 \\
$\mathrm{X}_{1}{ }^{2}$ & 0.020 & 0.751 & 2.280 & 0.004 & 0.003 & 0.014 \\
$\mathrm{X}_{2}(\mathrm{t})$ & 0.492 & 0.000 & 4.055 & 0.000 & 0.005 & 0.000 \\
$\mathrm{X}_{2}{ }^{2}$ & -0.030 & 0.586 & 0.183 & 0.707 & 0.002 & 0.015 \\
$\mathrm{X}_{3}($ prop $)$ & 0.412 & 0.000 & 2.605 & 0.001 & 0.004 & 0.002 \\
$\mathrm{X}_{3}{ }^{2}$ & -0.095 & 0.156 & 1.198 & 0.059 & 0.001 & 0.216 \\
$\mathrm{X}_{1} \mathrm{X}_{2}$ & 0.072 & 0.334 & 1.250 & 0.083 & 0.005 & 0.002 \\
$\mathrm{X}_{1} \mathrm{X}_{3}$ & -0.027 & 0.706 & 0.750 & 0.266 & 0.001 & 0.450 \\
$\mathrm{X}_{2} \mathrm{X}_{3}$ & 0.027 & 0.706 & 0.027 & 0.706 & -0.001 & 0.557 \\
\hline
\end{tabular}

(a)

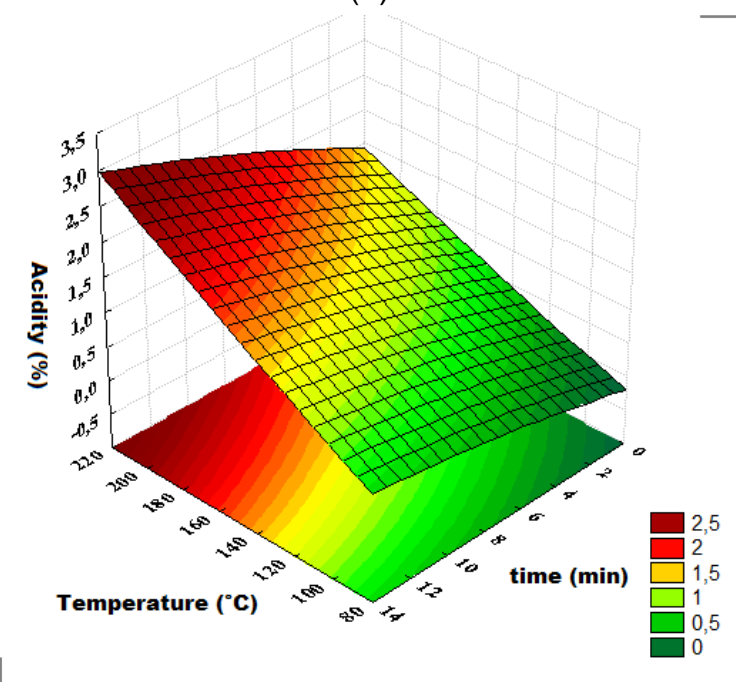

(b)

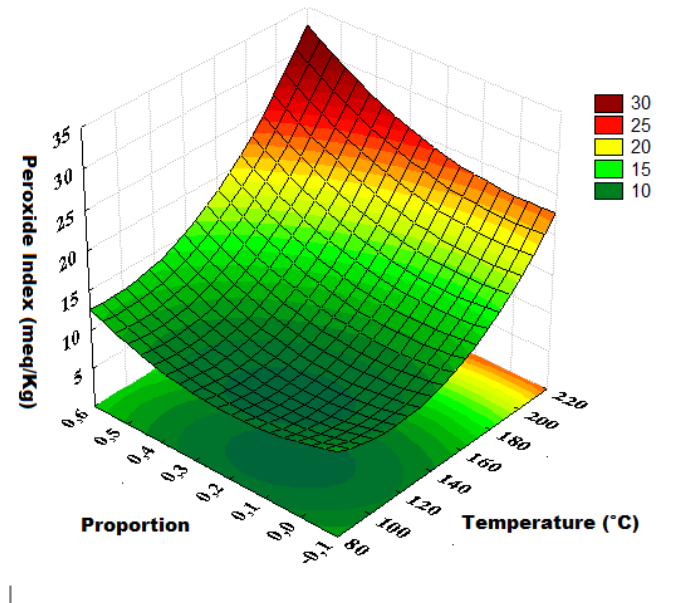

(c)

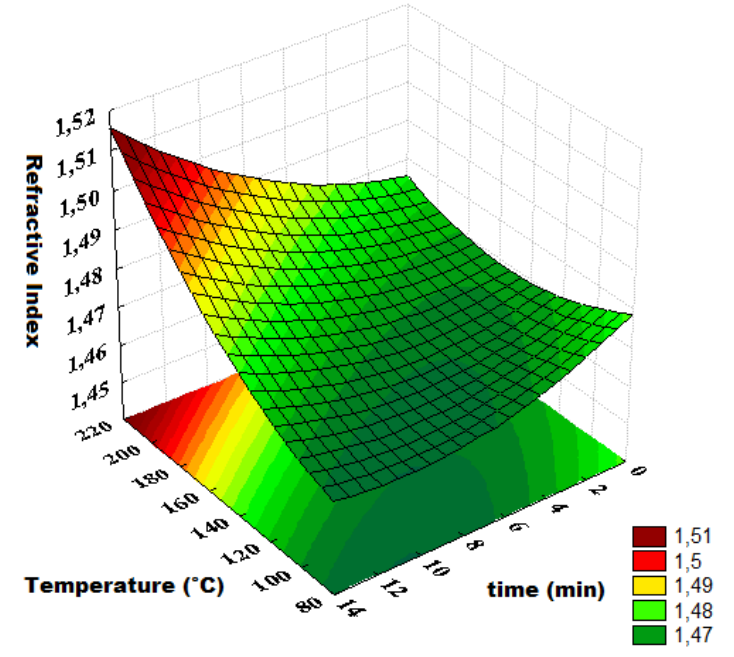

Figure 1 - Response surfaces of acidity (a), peroxide value (b) and refractive index (c) as a function of temperature and time.

Figure $1 \mathrm{~b}$ shows the relationship between the peroxide index response and the variables temperature and potato:oil ratio. A peak of degradation appears in the region in which the values of the variables are increased and the temperature affects the frying process more than the food ratio itself. 
In Figure 1c, it is possible to observe a linear and quadratic behavior of the variables in the refractive index response. Here again it has been observed that the combination between high temperatures and prolonged process times can be very detrimental to the oil used in the frying, which corroborates the previous analysis that warmer temperatures or shorter process times aid in maintaining the quality of the oil and, consequently, of the final product.

\section{Conclusions}

The temperature was the most significant among the studied variables, followed by the time and the potato:oil ratio. Empirical equations were extracted from the experimental data, showing good adjustment coefficients. It can be concluded that the frying process carried out at lower temperatures, despite making the process longer, contributes to increase the useful life of the oil used, directly impacting the quality of the final product.

\section{Acknowledgements}

To the Foundation for Research Support of the State of Minas Gerais (FAPEMIG) for granting financial support to the research, and to the Federal Institute of Education, Science and Technology of the Minas Gerais Triangle for structural support.

\section{References}

Ans VG, Mattos ES, Jorge N (1999) Avaliação da qualidade dos óleos de fritura usados em restaurantes, lanchonetes e similares. Ciêcia e Tecnologia de Alimentos [online] 19(3):413-419.

AOCS (2009) Official Methods and Recommended Practices of the American Oil Chemist's Society 6 ed., Champaign, vol. $1-2$.

Block JM, Barrera-Arellano, D (2009) Temas Selectos en Aceites y Grasas - Vol. 1. Ed Blucher, $1^{\text {a }}$ ed.

Brasil (2004a) Resolução RDC no 216, de 15 de set. 2004 da Agência Nacional de Vigilância Sanitária do Ministério da Saúde. Dispõe sobre Regulamento Técnico de Boas Práticas para Serviços de Alimentação. Disponível em http://portal.anvisa.gov.br/documents/33916/388704/R ESOLU

\%25C3\%2587\%25C3\%25830RDC\%2BN\%2B216\%2 BDE\%2B15\%2BDE\%2BSETEMBRO\%2BDE\%2B200 4.pdf/23701496-925d-4d4d-99aa-9d479b316c4b>. Acesso em: 06 set. 2016.

Brasil (2004b) Informe Técnico no 11, de 5 out. 2004 da Agência Nacional de Vigilância Sanitária do Ministério da Saúde. Óleos e gorduras utilizados em frituras. Disponível em: < http://www.anvisa.gov.br/ alimentos/informes/11_051004.htm >. Acesso em: 06 set. 2016.
Choe E, Min DB (2007) Chemistry of deep-fat frying oils. Journal of Food Science, 72(5): 77-86.

Del Ré PV, Jorge N (2007) Comportamento dos óleos de girassol, soja e milho em frituras de produto cárneo empanado pré-frito congelado. Ciência Agrotecnológica 31(6):1774-1779.

Dobarganes C (2000) Frying fats: quality control. In: International Workshop on Fats, Oils and Oilseeds Analysis. IUPAC book of conferences.

Embrapa (2016) Produtividade do Girassol. Texto de internet disponível em <https://www.embrapa.br/soja/cultivos/girassol>, acesso em dez 2016.

Food Ingredients Brasil (2014) Dossiê Óleos. Revista Food Ingredients Brasil 31: 38-55, disponível em $<$ http://www.revista-fi.com/materias/416.pdf>, acesso em dez 2016.

Freire PCM, Mancini-Filho J, Ferreira TAPDC (2013) Principais alterações físico-químicas em óleos e gorduras submetidos ao processo de fritura por imersão: regulamentação e efeitos na saúde. Revista de Nutrição 26(3):353-358.

Gimeno SGA, Mondini L, Moraes SAD, Freitas ICMD (2011) Padrões de consumo de alimentos e fatores associados em adultos de Ribeirão Preto, São Paulo, Brasil. Cadernos de Saúde Pública.

IUPAC (1979). Standard methods for the analysis of oils, fats and derivatives, 6a ed., Parte 1, seções I e II).

Jorge N, Soares BBP, Lunardi VM, Malacrida CR (2005) Alterações físico-químicas dos óleos de girassol, milho e soja em frituras. Química Nova 28(6):947-951 .

Lima JR, Gonçalves LAG (1994) Parâmetros de avaliação da qualidade de óleo de soja utilizado para fritura. Química Nova 17(5):392-396.

Monferrer A, Villalta J (1993) La fritura desde un punto de vista práctico. I. Alimentos - Equipos y Tecnología 21(3):85-90.

Osawa CC, Gonçalves LAG, Mendes FM (2010) Avaliação dos óleos e gorduras de fritura de estabelecimentos comerciais da cidade de Campinas/SP. As boas práticas de fritura estão sendo atendidas? Alimentos e Nutrição Araraquara 21(1):47-56.

Quadros DD, lung MC, Ferreira SMR, Freitas RD (2009) Composição química de tubérculos de batata para processamento, cultivados sob diferentes doses e fontes de potássio. Ciência e Tecnologia de Alimentos 29(2):316-323.

Silvani VAC, TAHAM T (2013) Influência de Parâmetros Operacionais na Qualidade de Óleos vegetais Submetidos a Processos de Fritura. In: SBOG 20 anos- Sociedade Brasileira de Óleos e GordurasAnais 20. 
USDA - United States Department of Agriculture (2011) The Oilseeds Group. World markets and trade 2001-2011. Washington: USDA, 2011. Disponível em: $<$ http://www.fas.usda.gov/

oilseeds/circular/2011/May/oilseeds.pdf>. Acesso em: novembro 2016.
Vernetti FJ (2015) Rural: Produção e consumo das principais oleaginosas até 2016. Diário Popular, disponível em < http://srvnet.diariopopular.com.br/04_02_07/p1601.html>, acesso em nov 2016. 